\title{
Nucleotide sequence and chromosomal location of Cabll and Cabl2, the genes for the fourth polypeptide of the photosystem I light-harvesting antenna ( $\mathrm{LHCI})$
}

\author{
Egbert Sehwartz', Dingren Shen², Ruedi Aebersold”. J. Mitchell MeGrath', Eran Pichersky' and Beverley \\ R. Green
}

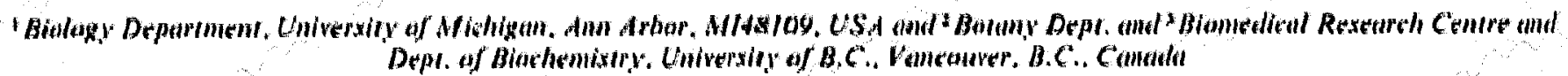

(Reeived 19 Deember 1990)

Tryple peplide sequenes from the $22 \mathrm{kDa}$ polypeptide or tomalo LHCI wepe used to consiruet a probe for tene eloning. The two genes eloned.

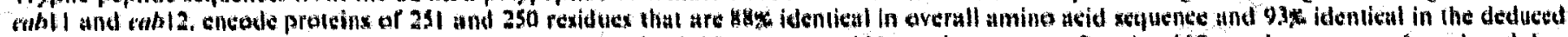

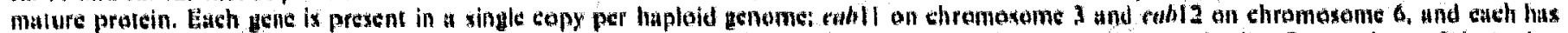

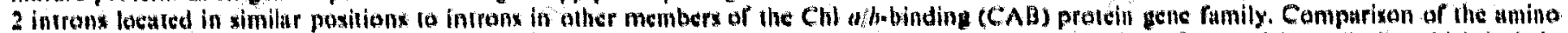

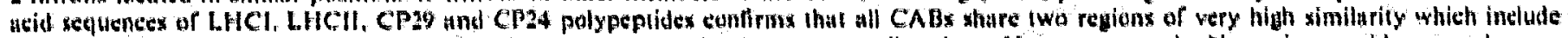

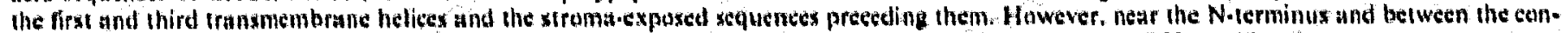
served repions. the LHC'l polypeptidex hive sequence morif's whish appedr to be DSI-specific.

Phetosystem I light-harvexting eamplex: Chlopsphyll abu(CAB) protein; Gene, rahll; Gene, rabl2: Lyrapersicum

\section{INTRODUCTION}

The chlorophyll $a / b$-binding (CAB) light harvesting antennas of higher plants comprise a diverse group of chlorophyll-protein complexes, one associated with Photosystem I (LHCI) and three with Photosystem II (LHCII, CP29 and CP24) [1-3]. Their polypeptides are immunologically rclated [4-6], and comparison of sequences obtained to date by gene cloning indicate that they are part of a large gene family $[7,8]$.

Genomic and CDNA clones encoding three of the four $\mathrm{LHCl}$ polypeptides have been isolated and characterized in tomato [9-12]. We report here the isolation and characterization of CDNA clones for 2 tomato genes, cab11 and cab12, which encode the fourth LHCI protein (Type IV). Comparison of the deduced amino acid sequences for all four of the LHCI polypeptides shows that while they are structurally related to the $C A B$ polypeptides of PSII in having the two highly conserved regions characteristic of all Chl $a / b$-binding polypeptides, outside of these regions they

Correspondence address: B.R. Green, Botany Department, University of B.C., B.C., Canada

Abbreviations: Chl, chlorophyll; PSI, Photosystem I; LHCI, Chla/b light-harvesting antenna of PSI; C.PI, PSI reaction centre complex; $\mathrm{CAB}, \mathrm{Chl} a / b$ binding have some unique sequence motifs which may be involved in their association with Photosystem $l$.

\section{METHODS}

2.1 Isolation and protein saquencing of tomalo L $\mathrm{HCl}$ polypeptides L.y cepersicon esculentum var. Best of All, was grown in a nixture of soil and vermiculite under natural illumination in a grcenhouse. PSI papticles (PSI-200) were made according to [13] with a Triton/Chl ratio of 6.25. L.HCl was prepared by solubilizing PSI.200 in $1 \%$ dodecyl malioside, $130 \mathrm{mM} \mathrm{NaCl}, 10 \mathrm{mM}$ Tricine, pH 8.0, and fractionating on a $0.2-1.0 \mathrm{M}$ sucrose gradien [14].

Polypeptides were separated by clectrophoresis for $22 \mathrm{~h}$ at $17 \mathrm{~mA}$ on $22 \mathrm{~cm}$ long $14 \%$ polyacrylamide gels containing $0.8 \mathrm{M}$ Tris, $\mathrm{pH}$ 8.8 , and $0 .: \%$ SDS, al $4^{\circ}[15]$ and electrotransferred onto nitrocellulose membranes for tryptic hydrolysis of inmunostaining; or onto polyvinylidene difluoride (Immobilon $P$ ) membranes for $N$. terminal sequeneing. LHCl was identified by Western blotting using antibodies raised against barley $\mathrm{CP}$ la $(\mathrm{CPI}+\mathrm{LHCl})$ [5]. Subunit II (psaD gene product) was identified using antisera donated by $D$ rs $R$. Malkin and N. Nelson:

Protcin bands on nitrocellulose membranes were cul out, digested on the support with trypsin [16] and separated by narrow-bore reversed phase HPLC on a Waters peptide analyzer equipped with a Vydac C.4 column. Individual peptides were collected manually and sequenced using standard pulsed-liquid-phase or solid-phase sequencing procedures [17]. For N-terminal sequencing, Coomassie-stained bands [18] were excised and sequenced in an Applied Biosystems Model 477 protein sequenator.

\subsection{Gene cloning and sequlencing}

Oligonucleotides were prepared using sequences derived from 2 of the tryptic peptides: for PGSVNQDPIF, the sense 20-mer 5'GT(A/T/G/C)AA(C/T)CA(G/A)GA(C/T)CC(A/T/G/C)AT(A/T- 


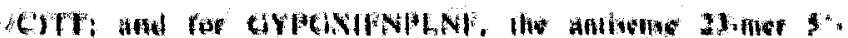

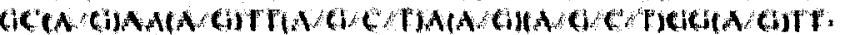

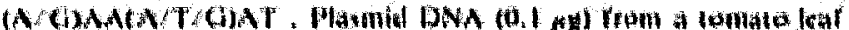

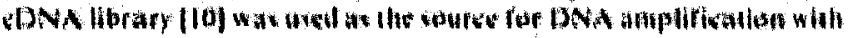

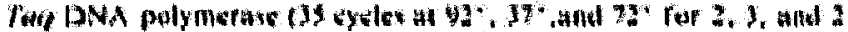
min repertively). Afler amplifkstion, toral amplified DNA was pass.

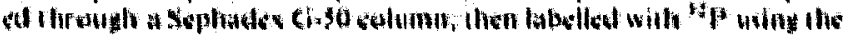
randem.primer metked. The labetled DNA was used a* a probe to

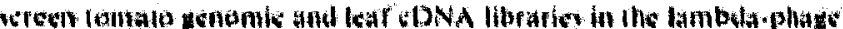
vectops Charon 15 and charon 16, respectisely $(10.19)$. Probe labat.

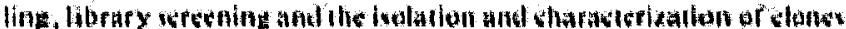

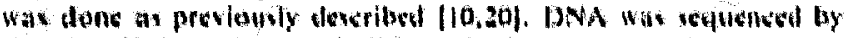

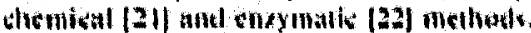

\section{RESULTS}

The resolution of tomato PSI-200 and LHCI polypepticles on a long separating gel is shown in Fig. 1 . The LECI polypeptides were elearly separated from the Subunit II (psaD) polypeptide, which was identified by Westorn bloting using two different antiscra (data not showlu). The $\mathrm{LHCl}$ polypeptides were immunostained (lane a) with antisera raised against the barley complex CPla (CPI + LHCl) (5). The lowest LHCl polypeptide (22 $\mathrm{kDa}$ ) was the most strongly stained band in all preparations. A similar predominance of one polypep.

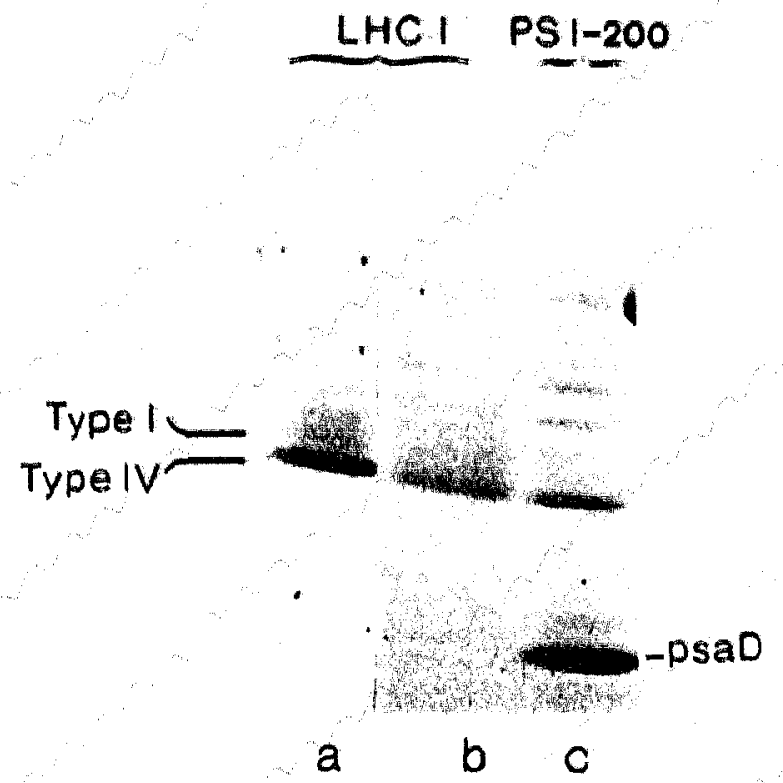

Fig. 1. Polypeplides of tomano L.HCI $(a, b)$ and PSI.20d (c) Lane s. immunodecoraned with ani.CPla, which resonizes the LHCI polypeprides [5]: hanes b. e, Coomassie sained. The psab polypepride whs identifled by immunoblotting wilh two independellt amiscra (dald not shown)
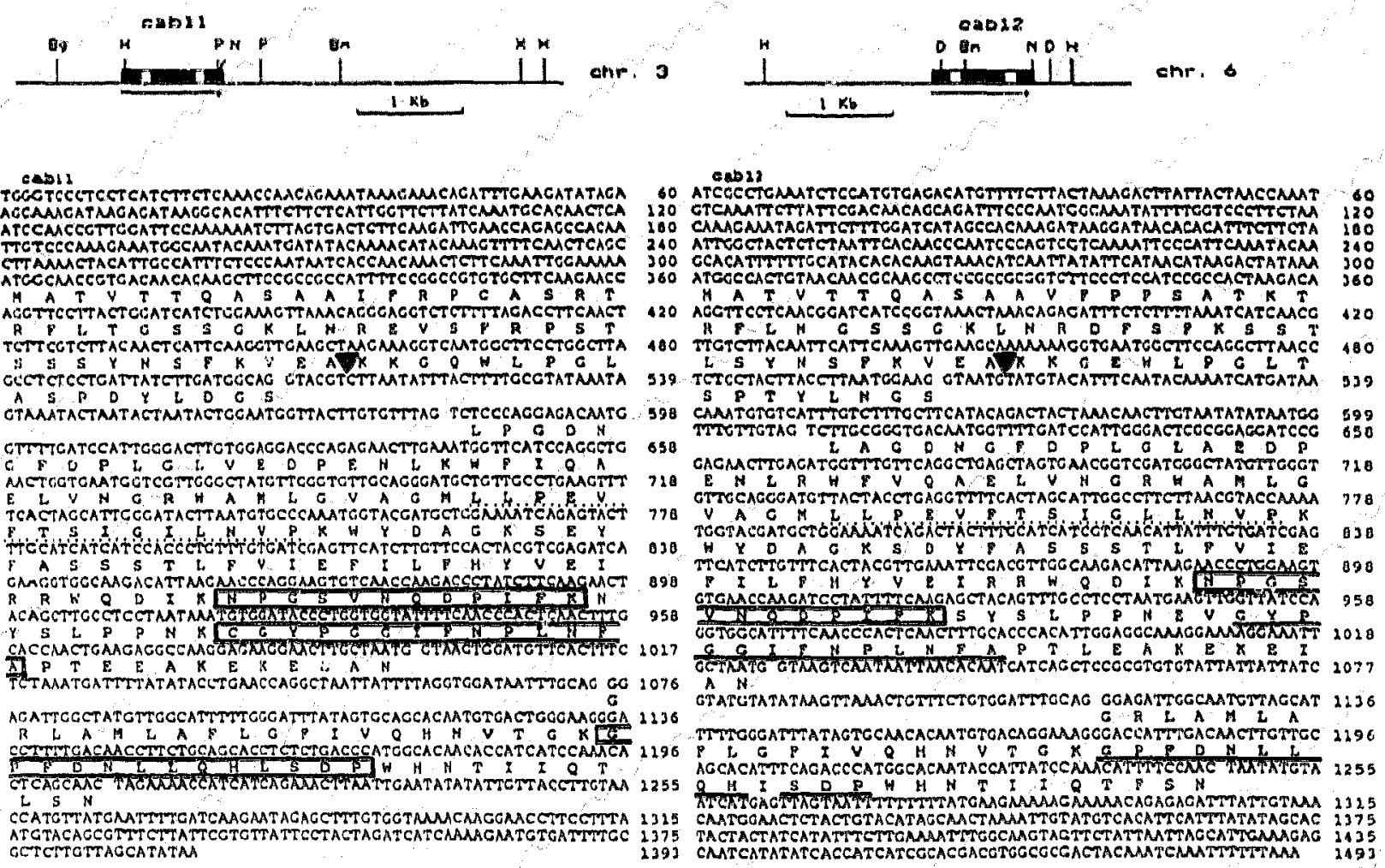

Fig. 2. Structure of cab1l and cab12. (Above) Restriction maps. Arrows indicale direction of transcription. Cleavage sites: Bg, Bgl Il; Bm, Bam HI; D, Dral; H, HindlII; N, Ncol; P, PSII; and X, Xbal. (Below) Nucleotide and deduced amino acid sequences. Intron positions were determined by comparison with cDNA clones. Exact matelies to $22 \mathrm{kDa}$ tryptic peptides XPGSVNQDPIFK, XGYPGXIFNPLNFA and XXXXNLLQXLSDP ate boxed ( $\mathrm{X}$ denotes amino acid not unambiguously identified); similar but not identical sequences are underlined in cabl2. Arrow-head denotes the most likely transit peptide cleavage site [28]. The sequence corresponding to the DCCD-labeled pea $20 \mathrm{kDa}$ polypeptide of [32] is underlined with dots. 
licle has been observed in L.HCt from some other higher plants $[23,24]$ and the green alga Colamydomonos rhetinhardrii (25). The antibody did not detect the minor polypepileles of 17 and $11 \mathrm{kDa}$ reported in maize and barley LHCI $[26,27]$.

The amino ateid sequened of three tryptic pepides from the $22 \mathrm{kDa}$ LHCl band (Type IV, Fia. I) were unl. que but elewrly related to sequences in the Type 11 and Type IIt tomato LHCI proteins $[11,12)$. Two of them sppeared to belong to adjacent regions by comparison with other CAB sequenes and were therefore used to prepare symbatic oligonueleoticles for amplification of the intepvening gene segment by the polymerase chain renction. The sequenee of ane tryptic peptide from the band labelled Type I (Fig. 1). (K)CIFPN, uniquely identified it as the C-terminus of cabsa, the first LHCI gene isolated [9].

The amplified DNA segmen was used as a probe to isolate two different cDNA clones and the corresponding genomic elones (Fig. 2). We designated the two genes cabll and cabl2; genes cabl through cablo $\mathrm{cn}$. code other CAB polypeptides of PSI and PSII $[7,8,19]$. The gene cabl 1 encodes a protein of 251 amino aeid residues, and cab 12 encodes a very similar polypeptide of 250 residues ( $88 \%$ overall sequence identity).

All 3 tryptie peptide sequenees derived from the 22 $k D a \mathrm{LHCl}$ band were identical to sequences encoded by cabll (boxed), and two were identical to cabl2-encoded sequences. Although the sequence XGYPGXIFN. PLNFA matched a cabl2 sequence it should not have been produced by tryptic cleavage of a $c a b 12$-encoded protein because the preceeding Lys has been replaced by Glu. The third sequence, NLLQXLSDP, differs in one residue ( $L$ instead of 1 ) from the corresponding cabl2 pepticle. This suggests that the cabll gene codes for most of the $22 \mathrm{kDa}$ LHCL polypeptide produced by tomato leaves. In our tomato cDNA library the frequency of clones for cab11 is approximately 100 times that of cab12; work is in progress to determine whether cabl2 mRNA is also rare in vivo.

Comparison of the sequences of the CDNA and genomic clones revealed that both cabl1 and $c a b 12$ contain two introns in identical positions (Fig, 2); the first intron is in the same position as an intron found in the Type II and Type III LHCI CAB genes and in the CP24 $C A B$ genes $[11,12,19]$; the second intron is in the same position as one found in the Type I LHCI CAB genes [9]. Since $c a b 11$ and $c a b 12$ have the same number and position of introns, as well as $88 \%$ sequence identity, we consider them both to be Type IV LHCI.

DNA from cabll and $c a b 12$ was used to probe Southern blots of tomato (Lycopersicon esculentum) and its close relative, $L$. pennellii, to determine if additional genes encoding the Type IV LHCI CAB protein existed in the genomes of these plants (Fig. 3). With one exception, only two hybridizing fragments were observed in all restriction digests probed with $c a b 12$ under

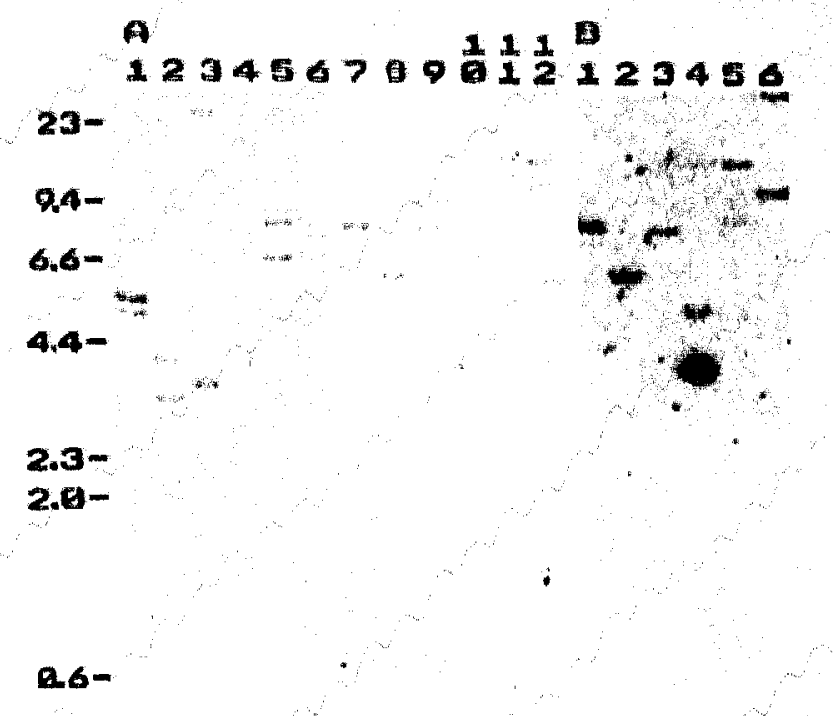

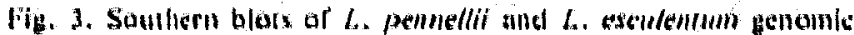
DNA. (N) Prubed with the $0.5 \mathrm{~kb}$ Neol mantht ragment from the cab12 sDNA clone. Oddinumbered lanes, I. peninelli DNA: cvell. number lanes, $L$. esculemhm DNA; digessed with Hindlif (lanes 1,2); Bs/ll (lanes 3,4). Abal (lanes 5,6): Dral (lanes 7, H): RooRV (lanes

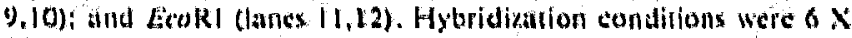
$\mathrm{SSC}^{\circ}, 65 \%$, washing conditions were $2 \times \mathrm{SSC}, 65 \%$, so that both Type IV genes were eleteted with the eabl2 probe. (B) Higher stringenty liybridization with the $0.7 \mathrm{~kb}$ Hindlll-Psi 1 fragment from the $\mathrm{cob} / \mathrm{l}$ -DNA elone. Lanes 1-6 are replieas of lanes 7-12 in (A). Hybridia. tion conditions as in $A$ but washed with $0.1 \times S S C, 65^{*}$. Numbers at lefi indiente position and size (in $k$ b) or marker rogmens.

low-stringency conditions (Fig. 3A, lanes 1-12), where the probe hybridizes with both cab 11 and $c a b 12$ genes (the second Dra I bands of about $1 \mathrm{~kb}$ are faint and may not be visible in the printed figure). The three hybridizing fragments in the EcoRI digest of $L$. pennellii (Fig. $3 \mathrm{~A}$, lane 11) are likely the results of an EcoRI site occurring inside one of these two genes. The fragments containing $c a b 11$ were identified under high stringency conditions (Fig. 3B, lanes 1-6). In the case of HindII, comparison of the $L$. esculentum restriction map (Fig. 2A) and the Southern blot (Fig. 3A, lane 2) showed that $c a b 11$ is on the $4.0 \mathrm{~kb}$ fragment and $c a b 12$ on the $3.0 \mathrm{~kb}$ fragment. The cloned Hindill fragments were finemapped and Southern blotted to rule out any tightlylinked duplications; no additional $\mathrm{CAB}$ genes were found (data not shown). We therefore conclude that $L$. esculentum and $L$. pennellii both contain the two genes encoding the Type IV CAB polypeptide of LHCI.

Due to the presence of polymorphisms in fragment sizes between the two species of Lycopersicon (Fig. 3), we were able to map the two loci in segregating F2's of the interspecific cross [20]. Results indicate that cab!] maps to chromosome $\overline{3}$, approximately $4 \mathrm{cM}$ from the marker TG242, and the cab12 gene maps to chromosomes 6 , approximately $7 \mathrm{cM}$ from marker TG275 (data not shown). 


\section{DISCUSSION}

LHCl can be subdivided into L.HCl.730 and L.HCl-680, with fluorescence emission maxima at 730 and 680 nim respectively $(23,28]$. I keuch et al. $[29]$ have peported partial peptide sequences from all four of the malure LHCl polypeptides of spinach and pea, in. cluding a spinach $20 \mathrm{kDa}$ polypeptide of LHCl-730 with an $N$-terminal sequence that closely matches that of tomato cabll and cabl2-encoded polypeptides, starting with Lys5l and Lys52 (Fig. 2, arrowheads). In tomato, most of this protein appeared to be $N$. terminally blocked, but a low level of elearly iden. firiable anino seidx were deteeted in eycles $4(\mathrm{Cln})$. $\sigma(L \mathrm{cu}), g(\mathrm{Lcu})$ and $10(\mathrm{~A} / \mathrm{a})$, sugesting that the transit peptide of the tomato Type IV preeurxor polypeptide is also removed at this point, giving a mature polypeptide or 200 rexidues. The faet that there is Gin rather than Glu at the 4th position and Als rather than Thr at the loth position is consistent with the tryptic peptide results which indicate that the dominant polypeptide in the tomato $22 \mathrm{kDa}$ band originates from cabll rather than eab12. By comparison with their peptide sequenees from spinach and pea, Ikeuchi et al. [29] also confirmed that the comato eab6 A, B (LHCl Type I) genes eneode the other LHC:-730 CAB polypeptide, and that the

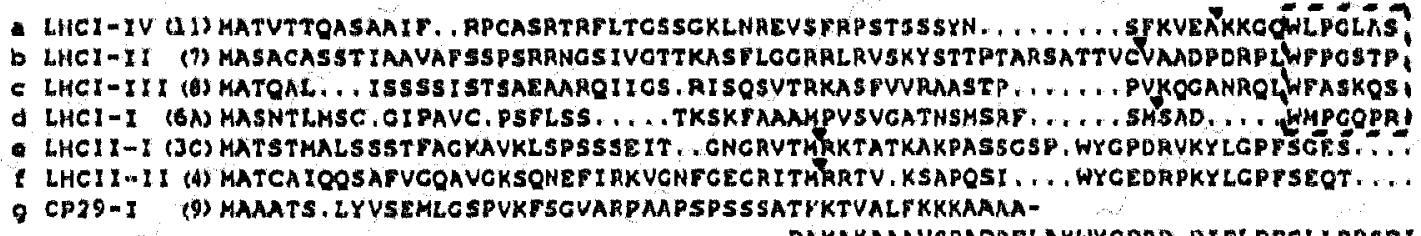

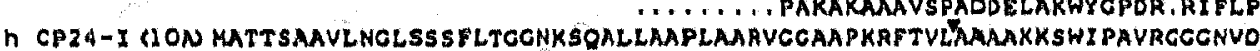

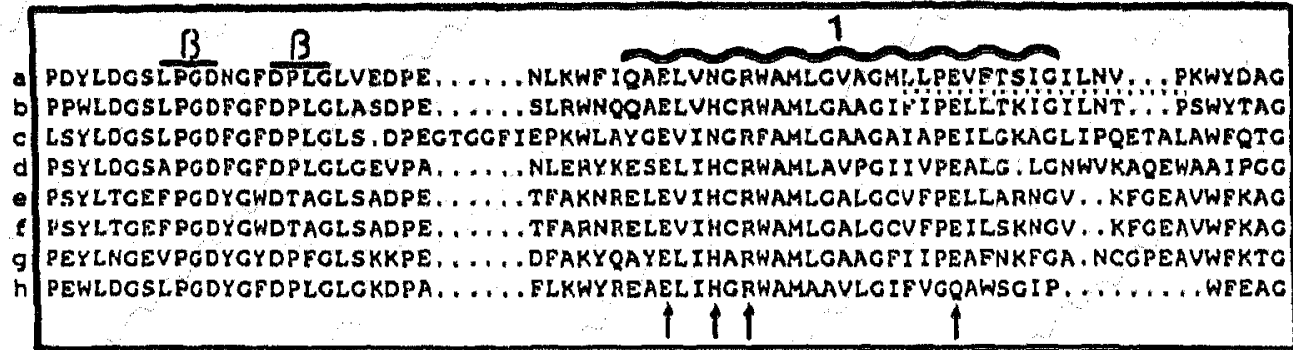

2

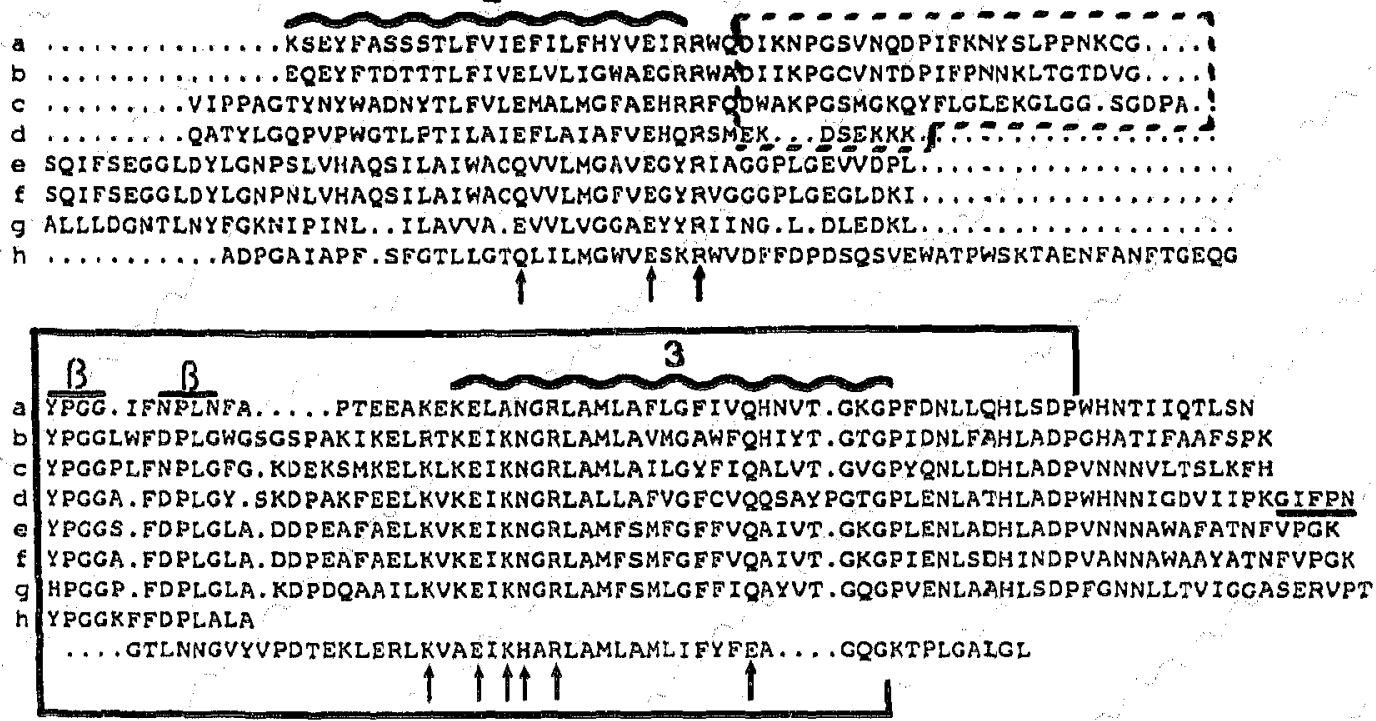

Fig. 4. Comparison of tomato $\mathrm{CAB}$ protein sequences. Thick wavy lines, predicted trans-membrane helices; betas, predicted beta turns. The two regions of high sequence similarity are enclosed in solid boxes. Sequence corresponding to pea $20 \mathrm{kDa}$ DCCD -labeled polypeptide [32] is underlined with dots. C-terminal tryptic peptide identifying cab6A polypeptide is underlined. Dashed boxes are proposed LHCl-specific motifs, Arrows poin to highly conserved residues discussed in text. (a) LHCI Type IV(cab11); (b) LHCI TypeII(cab7); (c) LHCI TypeIII(cab8), (d) LHCl Typel(cab6A) (e) LHCII Typel(cab3C); (f) LHCII Typell(cab4); (g) CP29 Typel(cab9); and (h) CP24 Type l(cab10A). 
tomato cab7 (L.HCl Type II) and tabs (L.HCI Type III) genes encote the two polypeptides of tomato LHCI.680.

Fin. 4 shows the deduced amino acid sequenees of the Pour types of LHCI genes lined up with the sequences for Type I and II LHCII (cab3 and $c a b 4)$. Type I CP29 (cab9) and the CP24 polypeptide (cablOA). All the pro. teins have three hydrophobie reglons long enough to be irans-membrane heliees (heavy wavy lines). There is a high degree of conservation ( $35 \%$ identity plus conservative substitutions) in the two homology regions diagnostic of CAB proteins (boxed). These regions include the first and third trans-membrane helices and the highly polar sequenees N-terminal to them which are enriched in turn-promoting amino acids (Asp, Gly, Pro). According to the euprent model for LHCII topology [30], the N-termini of helices $I$ and 3 are exposed on the stroma side of the thylakoid membrane. Within the highly conserved regions, all CABs should have the same folding pattern, with the core 3D conformations within $1.2-1.5 \AA$ (root mesn square deviation) of each other [31]. Direct evidence for the $22 \mathrm{kDa}$ polypeptide having the same relative orientation comes from DCCD-labelling of pea CAB polypeptides [32]. A DCCD-labeled CNBr fragment of a pea $20 \mathrm{kDa}$ polypeptide had the sequence LXPEVFTSIGIINVP which matches the corresponding $c a b 11$ and cabl2 sequences except for an Ile/Leu substitution (Figs 2 and 4). Since DCCD was used under conditions where it reacts with acidic residues in a hydrophobic environ. ment [32], this supports the location of a Glu within the first membrane-spanning helix.

Arrows in Fig, 4 mark the positions of conserved His, Asn and Gln residues that could be ligands to the $\mathrm{Chl}$ $\mathrm{Mg}^{+2}$ atoms, as well as several conserved Glu, Gln and Arg residues within trans-membrane helices. There are also a number of highly conserved Leu and aromatic residues. The conserved polar residues could be involv. ed in $\mathrm{H}$-bonding to polar groups on the porphyrin rings [33]. Note that there are a number of charged residues within the predicted trans-membrane helices; this is comparable to the situation in bacteriorhodopsin where the trans-membrane helices have a number of ionizable side-chains that are not part of the proton pore [34].

Differences between LHCI and the PSII CAB polypeptides can be seen in Helix 2 and the sequences flanking it. The PSI LHCI sequences have very short connectors between the first conserved region and Helix 2. With the exception of $c a b 6 \mathrm{~A}$, the LHCl's have longer connectors between Helix 2 and the second conserved region. In all four $\mathrm{LHCl}$ polypeptides, this connector has more positively-charged residues than in the PSII polypeptides. The CP24 polypeptide also has a long connector, but it has 6 negative charges and no detectable similarity with the other $C A B$ polypeptides. In addition to this region, predicted to be exposed on the stromal side of the membrane, there is a second motif near the $\mathrm{N}$-lerminus whieh appears la be L.HCl-speelfle (Fla 4). These motif sequenees could be Involved in specifie binding to the PSt core or other PSI proteins, of could be required ror targeting the protein to PSI during assembly of the holocomplex. In addition, Helix 2 appears to have some periodicity in conserved residues: this could indieate that one side of it is making specifie contaets with other proteins.

Acknowledtememr: Our work was mpporled by U.S. Depl ar Ayriculiure (EP), Natural Seicness and Engincering Reseapeh Counteil ar Canada (BRC) and Medizal Researel Counell af Canada (RA), Wo whould like lo thank Dry N. Neluon and R. Malkin ror their generous gifrs of antbodics, Drs J. Colbeck and I. Damm for helpful diseus. vons abou PSI, Drs P. Jahns, W. Junge and M. lkevehi ror com. musleation of unpublished resules, and Mr Ted Bures for expert rechnied hatp in protein xequencing.

\section{REFERENCES}

(1) Giecn, B.R. (1988) Phatosyn. Rex. 15, 3-32.

(2) Thophuer, J.P. (1986) in: Encyelopedia of Plant Plysiology 19 (New Series) (Stachelin, L.A. and Arntzen, C.J., edsis) Springer: Verlas. Berlin, pp, OS-142.

(3) Chitnik, P.R, and Thornber, J.P. (1988) Photoxyn. Res. 16. 41-63.

(4) Evans, P.K. and Andernon, J.M. (1986) PEBS Lai, 199. 227-213.

(5) White, M.J, and Gieen, B.R. (1987) Eur. J. Blochsm. 163, 545-55I.

(6) Darr. S.C., Somerville, S.C. and Arntken C.J. (1986) J. Cell Biol. 103, 733-740.

(7) Pichersky, E. and Oreen, B.R. (1990) Curr. Res. In Photosyn, 3. 553-556.

[8] Green, B.R., Pichersky, E. and Kloppstech, K (1991) Trends Biochem. (in press).

(9) Hoffman, N.E, Pichersky, E., Malik, V.S., Castresana, C. Ko, K., Darr, S.C. and Cashmorc, A.R. (1987) Proc. Natl. Acad. Sci. USA 84, 8844-8848.

(10) Pichersky, E., Hofiman, N.E., Malik, V.S., Bernalzky, R., Tanksley, S.D., Szabo, L, and Cashmore, A.R. (1987) Plane Mol. Biol. 2, 205-216.

[11] Picheisky, E., Tanksley, S.D., Piechulla, B., Stayion, M.M. and Dunsmuir, P. (1988) Plant Mol, Biol. 11, 69-71.

[12] Pichersky, E., Brock, T.G., Nguyen, D., Hoffman, N.E., Piechulla, B., Tanksley, S.D. and Green, B.R. (1989) Plant Mol. Biol. 12, 257-270.

[13] Mullet, J.E., Burke, J.J, and Arntzen, C.J. (1980) Plant Physiol, 65, 814-822.

(14) Haworth, P., Watson, J.L. and Aintzen, C.J. (1983) Biochim. Biophys. Acta 724, 151-158.

[15] Camm, E.L. and Green, B.R. (1989) Biochin. Biophys. Acta $974,180-184$

[16] Aebersold, R., Leavitt, J., Hood L.E. and Kent S.B.H. (1987) Proc, Natl. Acad. Sci. USA 184, 6970-6974.

[17] Aebersold, R., Pipes, G.D., Wettenhall, R.E.H., Nilco, H. and Hood, L.E. (1990) 187, 56-65.

[18] Matsudaira, P. (1987) J. Biol. Chem, 262, 10035-10038.

[19] Schwartz, E. and Pichersky, E. (1990) Plant Mol, Biol, 15, $157-160$.

[20] Pichersky, E., Bernatsky, R., Tanksley, S.D., Breidenbach, R.B., Kausch, A.P. and Cashmore, A.R. (1985) Gene 40. 247-258.

[21] Maxam, A.M, and Gilbert, W. (1980) Methods. Enzymol. 65, 499-560.

[22] Sanger, R., Nicklen, S. and Coulsen, A.R. (1977) Proc. Natl. Acad. Sci, USA 74, 5463-5467. 


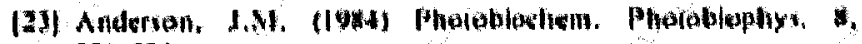
$251-238$.

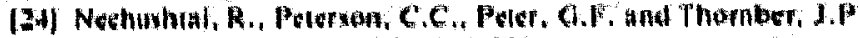
(1087) fiur. J. Biochem. 164, $145=390$.

(25) Herrin, D.h. Plumley, F.G., Ikeuchl, N., Mlketati, A.S. and

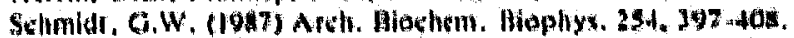

(26) Vaindein, A. Pelervon, C.C. and Thornber, J.P. (1949) 1. fiol, Chem. 20t, $4098-4061$.

[27] Anandan, S. Vwinwein. A. and Thornber. J.P. (1980) IEBS 1.e11. 256.150.134.

(28) Lam, E., Orik, W, and Malkin, R. (19t4) FES L.ell, 108, 10.14.

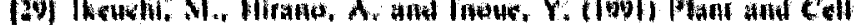
Phystal. (in procis).

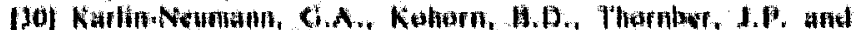

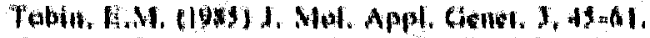

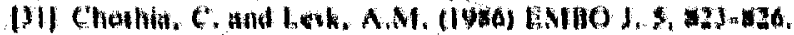

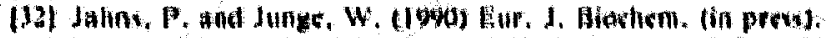

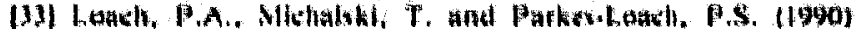
Curm, Rex. Phaldiyn. 2, 69-72.

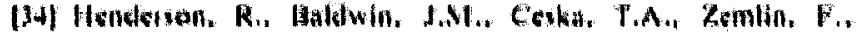

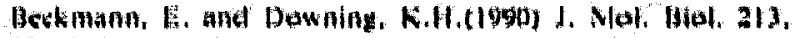
894.929. 